Assessment of Effectiveness of

Geologic Isolation Systems

\title{
Glaciological Parameters of \\ Disruptive Event Analysis
}

C. Bull

Ohio State University

April 1980

Prepared for the

Office of Nuclear Waste Isolation

under its Contract with the

U.S. Department of Energy

Pacific Northwest Laboratory

Operated for the U.S. Department of Energy

by Battelle Memorial Institute 


\title{
NOTICE
}

This report was prepared as an account of work sponsored by the United States Government. Neither the United States nor the Department of Energy, nor any of their employees, nor any of their contractors, subcontractors, or their employees, makes any warranty, express or implied, or assumes any legal liability or responsibility for the accuracy, completeness or usefulness of any information, apparatus, product or process disclosed, or represents that its use would not infringe privately owned rights.

The views, opinions and conclusions contained in this report are those of the contractor and do not necessarily represent those of the United States Government or the United States Department of Energy.

\author{
PACIFIC NORTHWEST LABORATORY \\ operated by \\ BATTELLE \\ for the \\ UNITED STATES DEPARTMENT OF ENERGY \\ Under Contract DE-AC06-76RLO 1830
}

\author{
Printed in the United States of America \\ Available from \\ National Technical Information Service \\ United States Department of Commerce \\ 5285 Port Royal Road \\ Springfield, Virginia 22151
}

Price: Printed Copy $\mathbf{s}$

$\because$ Microfiche $\$ 3.00$

NTIS

-Pages Selling Price

$\begin{array}{ll}001-025 & \$ 4.00 \\ 026-050 & \$ 4.50 \\ 051-075 & \$ 5.25 \\ 076-100 & \$ 6.00 \\ 101-125 & \$ 6.50 \\ 126-150 & \$ 7.25 \\ 151-175 & \$ 8.00 \\ 176-200 & \$ 9.00 \\ 201-225 & \$ 9.25 \\ 226-250 & \$ 9.50 \\ 251-275 & \$ 10.75 \\ 276-300 & \$ 11.00\end{array}$


$P N L-2863$

UC -70

\section{9}

Assessment of Effectiveness of Geologic Isolation Systems

GLACIOLOGICAL PARAMETERS OF DISRUPTIVE EVENT ANALYSIS

C. Bull

Ohio State University

Apri1 1980

Prepared for the

Office of Nuclear Waste Isolation

Under its Contract with the

U.S. Department of Energy

Pacific Northwest Laboratory

Richland, Washington 99352 
$\bullet$

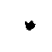




\section{PREFACE}

Associated with commercial nuclear power production in the United States is the generation of potentially hazardous radioactive waste products. The Department of Energy (DOE), through the National Waste Terminal Storage (NWTS) Program and the Office of Nuclear Waste Isolation (ONWI), is seeking to develop nuclear waste isolation systems in geologic formations. These underground waste isolation systems will preclude contact with the biosphere of waste radionuclides in concentrations which are sufficient to cause deleterious impact on humans or their environments. Comprehensive analyses of specific isolation systems are needed to assess the post-closure expectations of the systems. The Assessment of Effectiveness of Geologic Isolation Systems (AEGIS) Program has been established for developing the capability of making those analyses.

Among the analyses required for the system evaluation is the detailed assessment of the post-closure performance of nuclear waste repositories in geologic formations. This assessment is concerned with aspects of the nuclear program which previously have not been addressed. The nature of the isolation systems (e.g., involving breach scenarios and transport through the geosphere) and the great length of time for which the wastes must be controlled dictate the development, demonstration, and application of novel assessment capabilities. The assessment methodology must be thorough, flexible, objective, and scientifically defensible. Furthermore, the data utilized must be accurate, documented, reproducible, and based on sound scientific principles.

The current scope of AEGIS is limited to long-term, post-closure analyses. It excludes the consideration of processes that are induced by the presence of the wastes, and it excludes the consideration of nuclear waste isolation in media other than geologic formations. The near-field/near-term aspects of geologic repositories are being considered by OWNI/DOE under separate programs. They will be integrated with the AEGIS methodology for the actual site-specific repository safety analyses. 
The assessment of repository post-closure has two basic components:

- identification and analyses of breach scenarios and the pattern of events and processes causing each breach;

- identification and analyses of the environmental consequences of radionuclide transport and interactions subsequent to a repository breach.

The Release Scenario task of AEGIS is charged with identifying and analyzing breach scenarios and their associated patterns of events and processes.

The Release Scenario task is concerned with evaluating the geologic system surrounding an underground repository and describing the phenomena which alone or in concert could perturb the system and possibly cause a loss of repository integrity. Output from the Release Scenario task will establish the boundary conditions of the geology and hydrology surrounding the repository at the time of an identified breach. These bounding conditions will be used as input for the consequence analysis task, which will employ sophisticated hydrological transport models to evaluate the movement of radionuclides through the groundwater system to the biosphere.

AEGIS has contracted with a number of consultants to obtain expert scientific opinion about the geologic processes which could affect an underground repository. The consultants were asked to specify processes and events which might affect potential repository sites and, if possible, to give rates and probabilities for those phenomena. The consultants have also been involved with the description of the system interactions and synergisms.

This report contains information obtained by one of the AEGIS consultants during the FY-1978 research effort. The research described in this document is being continued during FY-1979 and FY-1980. Because of the ongoing nature of the Release Scenario methodology development effort, many of the results and conclusions outlined in this report are subject to change upon completion of additional research and analyses. The information contained in th is report is based upon the expert opinion of an individual consultant and should be treated as such. 


\section{CONTENTS}

PREFACE

FI GURES

ACKNOWLEDGEMENT.

SUMMARY

INTRODUCTION

WORLD-TO-SITE SPECIFIC COUPLING OF CONTINENTAL GLACIATION

EROSION RATES AND CONDITIONS

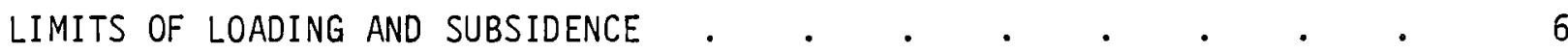

POTENTIAL FOR AND MAGNITUDE LIMITS OF DEEP GROUND-WATER RECHARGE . • $\quad 8$

POTENTIAL FOR AND CONSEQUENCES OF FRESH WATER FUMAROLES

ASSOCIATED WITH ICE LOADING .

FLOOD EROSION MAGNITUDES, RATES, AND DURATIONS . $\quad . \quad$. . . . 11

MAGNITUDES OF RIVER FLOODS . . . . . . . . . . . . . 13

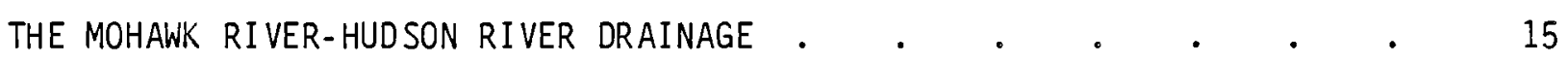

RAINFALL AND TEMPERATURE IN THE MODELS OF ICE-AGE CLIMATES • • • • 16

ISOSTATIC REBOUND RATES: POTENTIAL FOR AND MAGNITUDE OF FRACTURING $\quad$ - 18

STRESSES AND REBOUND RATES ASSOCIATED WITH ICE-SHEET LOADING AND

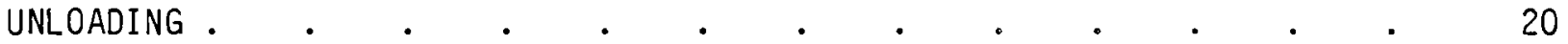

CONTINENTAL ICE MELTING - RIVERS OF LIMITED DURATION $\quad$ • $\quad$ • $\quad$ • $\quad 21$

CORRELATION OF CONTINENTAL GLACIATION EPISODES TO HARMONIC ANALYSIS

OR "MILANKOVITCH" STUDIES

CONTINENTAL GLACIATIONS AND HARMONIC ANALYSES OF "MILANKOVITCH"

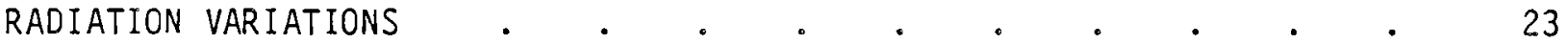

POSSIBLE EXTENT OF NORTH AMERICAN ICE SHEETS IN THE NEAR FUTURE • • 24

OTHER FACTORS CONTROLLING THE SIZE OF ICE SHEETS . . . • • . 27 
CONSIDERATION OF A PERMAFROST SITE IN NORTHERN ALASKA FOR NUCLEAR WASTE DISPOSAL

\section{REFERENCES}

APPENDIX

APPENDIX REFERENCES 


\section{FIGURES}

1 Calculation of Difference of Summer Precipitation in mm. Day-1 Between 18,000 Years B.P. and Present Day, by Members of CLIMAP Group

2 Oxygen Isotopic Composition of $G$. Sacculifera in Core V28-238 Complete Record to $1600 \mathrm{~cm}$, Expressed as Deviation 0/00 from Emiliani B1 Standard (From Shackleton and Opdyke 1973).

3 Known and Inferred Outer Limits of Four Glacial Stages in Central North America (Modified from Flint et al. 1959)

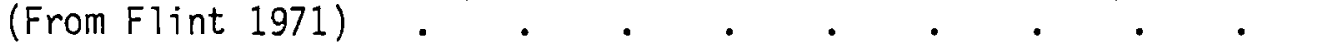

4 Part of John Hollin's Map of Mountain Glaciers in the U.S.A., 18,000 Years Ago, from CLIMAP. $. \quad . \quad . \quad . \quad . \quad$. 
,

$-$

- 1

1

, 


\section{ACKNOWLEDGMENT}

This research was supported by the Waste Isolation Safety Assessment Program (WISAP) conducted by Pac ific Northwest Laboratory. The program was sponsored by the Office of Nuclear Waste Isolation, managed by Battelie Memoriat Institute for the Department of Energy under Contract DE-ACO6-76RL0-1830. On 1 October 1979, WISAP became the Assessment of Effectiveness of Geologic Isolation Systems (AEGIS) Program and the Waste/Rock Interactions Technology (WRIT) Program. This report was issued by AEGIS. 


\section{SUMMARY}

Possible changes in the glaciological conditions on earth range from the growth of a complete ice cover over the entire globe to the complete deglaciation of the planet. Possible intermediate states include extensive reglaciations of the Northern Hemisphere and existence of conditions similar to those of the present.

The possibility of complete glaciation of the earth is small and probably need not be considered in the consequence analys is by the Assessment of Effectiveness of Geologic Isolation Systems (AEGIS) Program. One the other hand, abundant evidence exists that the quantity of ice on the earth has varied over the last million years. It is prudent to assume that the variations in ice cover will continue. Ice sheets formed during the next glaciation of North America could be up to $600 \mathrm{~km}$ more extensive than those of the Wisconsin glaciation. Within a few thousand years (unless man finds a way to control climate), an ice sheet may well cover proposed waste disposal sites in Michigan. Those in the Gulf Coast region and New Mexico are unlikely to be ice covered. The probability of ice cover at Hanford in the next million years is finite, perhaps about 0.5 .

Sea level will fluctuate as a result of climatic changes. As ice sheets grow, sea level will fall. In future glaciations, a sea-level drop of nearly 200 meters is possible. Melting of ice sheets will be accompanied by a rise in sea level. Within the present interglacial period there is a definite chance that the West Antarctic ice sheet will melt. There is a lesser chance that the Greenland ice sheet will melt in the same period. Sea level would rise about 7 meters if either the Greenland or the West Antarctic ice sheet melted. It is estimated, without much confidence, that the probability of the Antarctic ice sheet melting in the next million years is 0.25 . Such a melting, accompanied by melting of the Greenland ice sheet, would raise sea level by 60 to 70 meters.

Ice sheets are agents of erosion, and some estimates of the amount of material they erode have been made. As an average over the area glaciated by 
late Quaternary ice sheets, only a few tens of meters of erosion is indicated. There were perhaps 3 meters of erosion per glaciation cycle. Deep selective linear erosion can occur near the ice sheet margin, although the periphery of an ice sheet is normally a depositional environment. In future glaciations of North America, deep erosion by ice action will probably occur only in those areas where deep erosion has already occurred.

Under glacial conditions the surface boundary conditions for ground water recharge will be appreciably changed. Below the ice sheet or glacier, surface water will be under a hydrostatic pressure because of the load of ice. Free water will exist over appreciable areas of the ice sheet bed, and much of it will be available for recharge. Recharge may be greater under glacial conditions than under present conditions because of all-year recharge and the surface pressure conditions.

In future glaciations melt-water rivers generally will follow pre-existing river courses. With specific sites it should be possible to assess the possibilities of river erosion. Some salt dome sites in the Gulf Coast region could be susceptible to changes in the course of the Mississippi River. The New Mexico site, which is on a high plateau, seems to be immune from this type of problem. The Hanford Site is only a few miles from the Columbia River, and in the future, lateral erosion by the Columbia River could cause changes in its course.

Although the causes of ice ages are not known, a prudent assumption in the AEGIS study is that the present interglacial will continue for only a limited period, perhaps 4000 years, and that subsequently an ice sheet, at least equal in size to the Wisconsinan Laurentide and Cordilleran ice sheets, will form over North America. Other factors being equal, it seems unwise to site a nuclear waste repository (even at great depth) in an area likely to be glac iated. 


\section{INTRODUCTION}

In preparation for the workshop on the Waste Isolation Safety Assessment Program (WISAP) held at Seattle on 12 and 13 June 1978, and attended by most of PNL's consultants on geologic disruptive events, an ad hoc workshop on glaciology was held in Columbus, Ohio, on 12 and 13 May 1978. That ad hoc workshop was attended by: Dr. I an Whillans, Department of Geology and Mineralogy, The Ohio State University; Dr. Terence Hughes, Department of Geological Sciences, University of Maine; and Dr. Colin Bull, College of Mathematical and Physical Sciences, The Ohio State University. The questions addressed at that glaciology workshop constitute the section headings of this report. Much of the material that follows was generated at the ad hoc workshop. The remainder has been gained in subsequent library research and from discussions with other scientists. 


\section{WORLD-TO-SITE SPECIFIC COUPLING OF CONTINENTAL GLACIATION}

Possible changes in the glaciological conditions on Earth range from the growth of a complete ice cover over the entire globe (Budyko 1978) to the complete deglaciation of the planet. Possible intermediate states include extensive reglaciations of the Northern Hemisphere and existence of conditions similar to those of the present.

The possibility of complete glaciation of the earth is small and probably need not be considered in the consequence analys is by the Assessment of Effectiveness of Geologic Isolation Systems (AEGIS) Program. On the other hand, abundant evidence exists (e.g., Hays et a1. 1976; Kennett and Shack leton 1975; Shackleton and Opdyke 1973) that the quantity of ice on the earth has varied, at least over the last million years. For the last 600,000 years, the cycles have had a period of about 100,000 years. The cause of the variations is not known; it may be variations in the solar constant, changes in the geometry of the earth-sun system (Weertman 1976) variations in the microparticle content of the atmosphere (Gow and Williamson 1971; Thompson et a1. 1975; Hammer 1977) or other phenomena.

In any case, it is prudent to assume that the variations in ice cover will continue. The next glaciation of North America (and other parts of the Northern Hemisphere) could correspond with an ice volume of -1 on the scale of Shackleton and Opdyke (1973), which is equivalent to ice sheets up to $600 \mathrm{~km}$ more extensive than the Wisconsinan Ice Sheet was in the low-lying areas of North America. On Berger's model, presented by M. Schwartz at the Battelle Workshop, this reglaciation could start in 4000 A.P (years after the present). After that time, according to the Milankovitch model, the next significant "low" in Northern Hemisphere solar radiation appears to be in 60,000 A.P. The probability that continental ice will cover Columbus, Ohio (near the maximum of the Wisconsinan glaciation), within the next 4000 years or so has been estimated variously at 0.25 to 0.50 . The probability of at least one such glaciation in the next million years is close to 1.

It must be emphasized that these probabilities are based on the assumption that man's technology will not have advanced to the stage where, within 
4000 years, he will be able to control climate to the extent necessary to offset the effects of natural variations, Milankovitch or otherwise (Kellogg 1978). The present writer, without substantial evidence, believes that such technology (perhaps for controlling $\mathrm{CO}_{2}$ content of the atmosphere) will develop.

Ignoring such possible control, within a few thousand years an ice sheet may well cover proposed waste disposal sites in Michigan. Potential sites in the Gulf Coast region and New Mexico are unlikely to be ice covered. The extent of mountain glaciation at the Wisconsin maximum has been mapped, as part of the CLIMAP program, by John Hollin (unpublished). The area in southeastern Washington on which the Hanford Site is now located was not ice covered, but the ice edge of mountain glaciation was only scores of kilometers away. Also, lobes of the Cordilleran ice sheet (responsible in part for the Lake Missoula floods) invaded the northern part of Washington State. The probability of ice cover at the Hanford Site in the next million years is finite, perhaps about 0.5 .

The reconstructions of the Wisconsin ice sheet in North America (Sugden 1977; CLIMAP project members 1976), when extended to other parts of the northern hemisphere, indicate a minimum sea-level drop at 18000 B.P. (years before the present) of 126 meters and a maximum of about 165 meters. With a glaciation equivalent to -1 on Shackleton and Opdyke's scale, a sea-level drop of nearly 200 meters is possible. At the Battelle Workshop, M. Schwartz, an expert on sea-level fluctuations, gave a comparable estimate for the maximum possible sea-level drop.

Within the present interglacial period there is a definite chance that the West Antarctic ice sheet will melt. Increased temperatures resulting from increased $\mathrm{CO}_{2}$ in the atmosphere could be the cause of this melting (Broecker 1975; Mercer 1978). The probability is estimated at less than 0.1. Such a melting would cause a sea-level increase of about 7 meters. There is a lesser chance, perhaps 0.05 , that the Greenland ice sheet will melt in the same period, although it can be considered as not being in equilibrium. If it 
melted, the Greenland ice sheet would not regenerate under present climatic conditions. Sea level would rise about 7 meters if the Greenland ice sheet melted.

With increased atmospheric temperatures in the Antarctic there would be a slow change in basal temperatures of the ice sheet. There would also be a change from freezing to melting conditions in significant areas of East Antarctica (Weertman 1966; Nye 1976), perhaps accompanied by major surges of the ice sheet (Hollin 1977), changes of the earth's albedo, and the initiation of Northern Hemisphere glaciations (Wilson 1964). Changes in atmospheric temperature may not be necessary to initiate the surges (Budd 1975).

There is no evidence that the Antarctic ice sheet has disappeared completely in the last 4 million years (e.g., Drewry 1976; Stuiver et al. 1976; Mayewski 1975; Calkin et a1. 1970). On this lack of evidence it is estimated, without much confidence, that the probability of the Antarctic ice sheet melting in the next million years is 0.25 . Such a melting, accompanied by melting of the Greenland ice sheet, would raise sea leve 1 by 60 to 70 meters (Hollin 1962). In the next 4000 years the maximum sea-level increase, resulting from melting of the Greenland and West Antarctica ice sheets, may perhaps be about 12 meters.

There is little chance, perhaps 0.1 , that the Greenland ice sheet will remain intact for 1 million years. Either Greenland or West Antarctica may have been not covered in the last interglacial, when sea level was a few meters higher than at present (Shackleton and Opdyke 1973; Shackleton and Matthews 1977; also M. Schwartz at Battelle Workshop). 


\section{EROSION RATES AND CONDITIONS}

An extreme view of the erosive powers of continental ice sheets is given by White (1972), who argues that the late Quaternary ice sheets of North America caused erosion of hundred of meters into the Canadian Shield. Mathews (1975) and especially Sugden (1976) contend that, as an average over the glaciated area, only a few tens of meters of erosion (which may be of previouslyweathered regolith as opposed to bedrock) is indicated. There was perhaps 3 meters of erosion per glaciation cycle. Sugden (1976 and 1977) argues that deep selective linear erosion can occur near the ice sheet margin, although the periphery of an ice sheet is normally a depositional environment. Erosion at the ice sheet margin is accomplished by streams that are produced by local thawing of the ice base. The Finger Lakes are an example of erosional features formed near the margin of an ice sheet.

The erosion of the basins of the Great Lakes is probably also due to icesheet action, possibly associated with fracturing of the crust under the icesheet load (Brotchie and Silvester 1969). As far as is known there are no "relict Great Lakes." Lakes which were cut out perhaps 500,000 years ago have not been filled with Quaternary material, as would be the case if centers of erosion had shifted elsewhere in later glaciations. The absence of these relict lakes leads one to conclude that in future glaciations of North America, deep erosion by ice action will occur only in those areas where deep erosion has already occurred.

From the quantity of sediments carried to the deep Atlantic by ice rafting and other means, Ruddiman (1977) calculated that an average of 16 meters of material had been eroded in the last 3 million years. Lane (unpublished), in a similar study, obtained 20 meters. These are likely to be minimum erosion rates, because these studies ignore the erosion products in solution and fine suspension. 


\section{LIMITS OF LOADING AND SUBSIDENCE}

The two best reconstructions of the Laurentide ice sheet of North America (Sugden 1977 and CLIMAP group) give similar values for the extent, thickness and bottom conditions. Sugden's model, based on the form of the Greenland and Antarctic ice sheets, gives a maximum ice thickness of $4244 \mathrm{~m}$ in the westcentral part of Hudson Bay. The CLIMAP reconstructions attempt to use more glacial geologic control, in which the bottom conditions are first inferred from observed erosion and depositional patterns, and so on. The "maximum" model has a maximum ice thickness of $4960 \mathrm{~m}$ west of Hudson Bay. The "minimum mode1" gives three "domes"; one dome has a thickness of $4260 \mathrm{~m}$ west of Hudson Bay, the second dome has a thickness of $4230 \mathrm{~m}$ over James Bay, and the third dome is a lower one over Fox Basin.

Loads of specific points can be calculated directly from the reconstruction maps of ice thickness. Future ice sheets may be more extensive than the Laurentide; the ice-sheet margin could be up to 600 kilometers further south in the U.S. Midwest, as in the "Kansan" stage (Flint 1971). The form of the profiles of the more extensive ice sheets should closely resemble those of the Laurentide ice sheet, with maximum thicknesses increased by only a few hundred meters over the Laurentide values.

Members of CLIMAP have calculated depressions of the earth's crust using two different models. In one model, the isostatic processes are assumed to occur in the crust (so that the density ratio of ice: displaced material is $1: 3$, and the maximum depression is thus about 1500 meters). In the other model, isostatic adjustments occur in the mantle (giving a density ratio of $1: 4$ and a minimum value for the greatest depression of about $1000 \mathrm{~m}$ ). See Brotchie and Silvester (1969).

Permeabilities of earth material below the ice sheet at equivalent elevations relative to a fixed datum should not be affected by ice-sheet loading and subsequent subsidence.

Loading and subsidence due to reglaciation of North America are not likely to directly affect proposed disposal sites in the Gulf Coast region or 
New Mexico. A Columbia River Plateau site could be affected by the "forebulge" (Brotchie and Silvester 1969) from a Cordilleran ice sheet, but change of elevation is not likely to exceed a few meters. Similarly, changes in elevation at a Columbia River Plateau site due to the direct depression, or forebulging, from a neighboring mountain ice cap are not likely to be significant.

Loading of the Gulf of Mexico might produce a sea-level fall of 200 meters or a sea-level rise of 70 meters. The eifect of these changes on the proposed disposal sites in the Gulf Coast region should be calculated, but it does not seem likely that they will be significant. 


\section{POTENTIAL FOR AND MAGNITUDE LIMITS OF DEEP GROUND-WATER RECHARGE}

Under glacial conditions the surface boundary conditions for ground-water recharge will be appreciably changed. Below the ice sheet or glacier, surface water will be under a hydrostatic pressure due to the load of ice. This pressure may be up to more than 400 bars where the ice sheet is thickest. Free water will exist over appreciable areas of the ice sheet bed. The areas of melting under the Laurentide ice sheet are shown in the maps of Sugden (1977) and of the CLIMAP group. The melt water is generated by the geothermal heat flux, which varies over the area of the Laurentide ice cover from 1 to about $1.7 \times 10^{-6} \mathrm{cals} \mathrm{cm}^{-2} \mathrm{sec}^{-1}$ (Sugden 1977). Melt water is also generated by the frictional heat produced by ice slipping over the bed and by internal deformation near the base of the ice sheet. The quantity of free water generated varies under these conditions between $0.5 \mathrm{~cm}$ and about $3.0 \mathrm{~cm}$ per year, but it is nearly all available for recharge. Small amounts may move to the "freezing" zones of the ice sheet bed, and some melt water may be forced to the edge of the ice sheet where it can escape.

Under non-glacial conditions in this part of North America, the surface may be frozen for appreciable parts of the year and completely dry during other periods. Furthermore, evaporation and temperature gradients in the surface layers may also cause moisture loss. Hence, although the total annual precipitation now greatly exceeds $3 \mathrm{~cm}$, the recharge may be greater under glacial conditions because of all-year recharge and the surface pressure conditions.

Sugden's model of the Laurentide ice sheet gives a continuous frozen zone that is several hundred kilometers broad. The CLIMAP model shows sporadic frozen patches, based on the glacial geology rather than on calculations. However, as the ice sheet varies in size, all sub-glacial areas will be covered by melting ice.

The possibility exists that recharge water under the central part of the ice sheet will be forced to appreciable depths. It might then flow under the frozen zone and return to the surface near the edge of the ice sheet, where 
surface pressures are low (McGinnis 1968). Other factors being equal, it seems unwise to site a nuclear waste repository (even at great depth) in an area likely to be glaciated.

Beneath the sliding parts of the ice sheet all of the regolith and underlying permeable rock must have been saturated (Weertman 1966). The planing of the Canadian Shield and the gouging-out of the Great Lakes indicate that such sliding has occurred (and, therefore, saturation of underlying materials) for appreciable parts of each glacial cycle.

These considerations of deep recharge under the ice sheet are not likely to affect Gulf Coast and New Mexico sites because of their isolation from the ice. However, under extreme mountain glaciation conditions, or with a more extensive Cordilleran ice sheet, a Columbia River Plateau site could be in an area affected by upward movement of deep recharge waters near the ice edge. 


\section{POTENTIAL FOR AND CONSEQUENCES OF FRESH WATER}

FUMAROLES ASSOCIATED WITH ICE LOADING

Other than the discharge of deep recharge water near an ice sheet edge due to strong horizontal gradients of surface hydrostatic pressure, there seems no real possibility that glacial-related, fresh water fumarolic action wi11 be important in waste disposal site considerations. 


\section{FLOOD EROSION MAGNITUDES, RATES, AND DURATIONS}

During variations in the lateral extent of an ice sheet and its lobes, floods causing extensive erosion can be caused by the release of large trapped bodies of water. Large lakes can be formed by the blocking of normal outlets by a lobe of an ice sheet or a mountain glacier. Subglacial lakes can be formed in existing basins (e.g., Lake Erie) and can be suddenly discharged as the edge of the ice sheet retreats to a critical point.

Extensive lobes of an ice sheet may be generated around its periphery by changes in the basal thermal conditions (Weertman 1966).

The Superior and Des Moines lobes of the Laurentide ice sheet (Wright and Matsch 1973) were probably formed in this way, as a previously frozen area of the ice-sheet bed to the north melted. The Des Moines lobe extended several hundred kilometers to the south, but it may only have occupied its forward position for a few thousand years. Thus, there may have been several earlier "Des Moines lobes" during the Wisconsin glaciation. Lakes of the Missoula type, which were trapped and released as the eastern Washington lobe advanced and retreated (D. Tubbs at Battelle Workshop), may have caused a dozen Missoula floods in a period of 100,000 years during the Wisconsinan stage.

Similarly, sub-glacial Great Lakes could have discharged catastrophically. Kennett and Shackleton (1975) interpret the oxygen isotope anomalies in Gulf of Mexico cores "as representing the massive inpouring of glacial melt water ... via the Mississippi ... during the early melting phases of the last Wisconsin Laurentide ice sheet," between 12000 and 16000 years ago. Large ancient river channels associated with the Mississippi River system are direct evidence of southward melt water transport to the Gulf of Mexico ( $\mathrm{Clark}$ and Stearn 1968). As the ice sheet retreated, melt water could flow eastwards. Much of the erosion of the Mohawk valley is probably due to glacial melt water, though the valley may have served as a discharge course repeatedly during the last million years.

The quantity of water discharging into the Gulf of Mexico in that period should be calculable from the changes in salinity and oxygen ratios from the 
cores (Kennett and Shackleton 1975; Emiliani et al. 1975). Similar calculations are possible based on assumed ablation rates on the ice sheet itself.

In future glaciations melt-water rivers in general will follow preexisting river courses. With specific sites it should be possible to assess the possibilities of river erosion. Some salt dome sites in the Gulf Coast region could be susceptible to changes in the course of the Mississippi River. The New Mexico site, on a high plateau, seems to be immune from this type of problem. The river erosion could possibly affect a Columbia River Plateau site. In the future, lateral erosion by the Columbia River could cause changes in its course, possibly affecting the integrity of a repository in the Columbia River Plateau basalts. 


\section{MAGNITUDES OF RIVER FLOODS}

At the time of the maximum of the Laurentide ice sheet, and during the first part of its recession stage, probably one-third and possibly one-half of the total ablation (as melt water) from the ice sheet drained into the Mississippi River system. Later, as the ice sheet edge retreated northwards, drainage paths eastwards to the North Atlantic ocean were opened, and most of the melt water from the Great Lakes area of the ice sheet was diverted from the Mississippi. The first change occurred about 12,800 years B.P., when the icesheet area was still about 60 percent of its maximum. At that time the Hudson River drainage path was opened. This was the main outflow path for a relatively short period, perhaps 1000 years, until the St. Lawrence pathway opened, about 11,800 years B.P. (Kennett and Shackleton 1975).

In principle, one should be able to calculate the volume of the Mississippi water flow during the early ice sheet recession period. This calculation would be done by using the change in the stable oxygen isotope ratio, especially of the surface layers, of the waters of the Gulf of Mexico in the period from about 15,000 to 12,000 years B.P. With reasonable assumptions for tie oxygen isotopic content of glacial melt water, Kennett and Shackleton (1975), from an examination of three cores from the western half of the Gulf of Mexico, suggest that the surface waters (less than 100 meters, but the actual thickness unknown) were diluted with river water by more than 8 percent. Deeper waters were diluted by more than 4 percent.

To complete the calculation of river flow rates, one needs a close knowledge of the mixing characteristics in the Gulf at a time when sea level was below the present level by perhaps about 80 meters. Curray (1965) gives a model for the distribution of surface-sediment facies, and directions for transport of material on the continental shelf of the Gulf, but the author has not been able to gain reliable information on vertical mixing or water "residence" times in the Gulf. The present water flow from the Mississippi apparently has little dilution effect at the sites of Kennett and Shackleton's cores; it is negligible compared with the amount of dilution at 13,500 years B.P. 
An alternative attack on the problem is to calculate the ablation of ice during the "retreat" phase of the Laurentide ice sheet. The southern limit of the large Erie Lobe retreated across Ohio from its southernmost extent near Chillicothe to the position of Lake Erie in about 3000 years. Its velocity was about $0.15 \mathrm{~km} \mathrm{yr}^{-1}$ (R. P. Goldthwait, lecture notes; see also Goldthwait et al. 1965). Brotchie and Silvester (1969), in their calculations of iso-

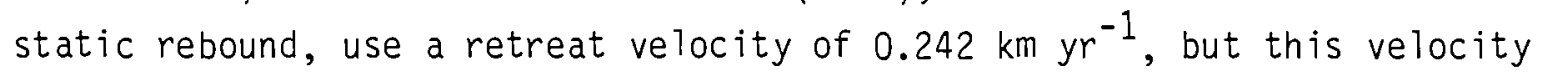
was calculated for a later stage of the ice-sheet disappearance.

Under certain assumptions, an estimate of annual river flow was made. It was assumed that: the profile of the ice sheet remained the same during the retreat (so that the elevation in the center changed by only 200 meters or so); the snow accumulation pattern was the one given by Sugden (1977), and it remained unchanged during this retreat phase; the precipitation over the rest of the drainage basin of the Mississippi was the same as it is presently; and the retreat of the rest of southern border of the ice sheet was at the same rate as in Ohio. With these assumptions, the estimates obtained for annual river flow are about ten times the present annual volume. This increase seems small compared with the conclusions from the deep sea core studies. 


\section{THE MOHAWK RIVER-HUDSON RIVER DRAINAGE}

The main part of the east-flowing drainage of melt water from the retreating Laurentide ice sheet was carried by the Mohawk River for only a short period. Wayne and Zumberge (1965) estimate the period as 2000 years, from 12,500 B.P. to about 10,500 B.P. Kennett and Shackleton (1975) quote sources who, using additional radiocarbon datings, give the period as 800 or 1,000 years, from 12,800 B.P. to 12,000 or 11,800 B.P.

The main part of the Hudson trench and the Mohawk trough are assumed to be preglacial but "only in the lower course of the Hudson can remnants of preglacial channels be established" (Mueller 1965). Drillings and seismic soundings show that the bedrock trough at Catskill is more than $230 \mathrm{~m}$ deep and at Tappan Zee is $225 \mathrm{~m}$ deep. However, from the fiord-like characteristics, it may be assumed that most of the erosion was glacial. A great amount of time and effort would be required to determine the amount of erosion in the Mohawk and Hudson River valleys that can be attributed safely to the "flood stage," when that course carried most of the eastward-flowing water from the retreating ice sheet.

Almost certainly, the valleys have been repeatedly occupied by ice and also by "flood stage" rivers, so that t e erosion associated with one glacial cycle seems likely to be small, probably not exceeding 30 meters.

It is worth noting Mueller's suggestion that the present alignment of the lower part of the Hudson River may diifer from the preglacial course due to glacial derangement. In general, the rivers have probably remained in the same valleys throughout the pleistocene. 


\section{RAINFALL AND TEMPERATURE IN THE MODELS OF ICE-AGE CLIMATES}

In the two best model simulations of the climate during the last ice age (Williams et a1. 1974; Gates 1976), the inference of surface temperatures over the North American land mass appears to be sound. The input data in the models are the surface air temperatures over the oceans. In general, these air temperatures are obtained from ocean surface temperatures, which are inferred from the fossil content of ocean sediment cores. Fossils of surfaceliving specimens and knowledge of their sensitivity to temperatures are used to estimate past ocean surface temperatures. The output from the models includes the land temperatures. Model predictions may be checked by comparing them to information about the past climate that has been inferred from pollen and other field records.

From the temperature data over land and ocean, the next step is to obtain the atmospheric pressure fields near the earth's surface. The wind patterns can be obtained from the atmospheric pressure fields. Assumptions on cloudiness are built into the models, and from those cloudiness assumptions and the wind patterns, precipitation is predicted. Thus, the precipitation pattern is two or more steps removed from the basic output of the models and is the least reliable output. In a few places, pollen records exist in which some species may be sensitive to both temperature and precipitation. However, both the NCAR mode 1 used by Williams and others and the RAND model used by Gates predict drier conditions over most of North America during the ice age, than those that now exist (Figure 1). (This section is a summary of T. Hughes' statement during the ad hoc glaciology workshop, May 1978, Columbus.) 


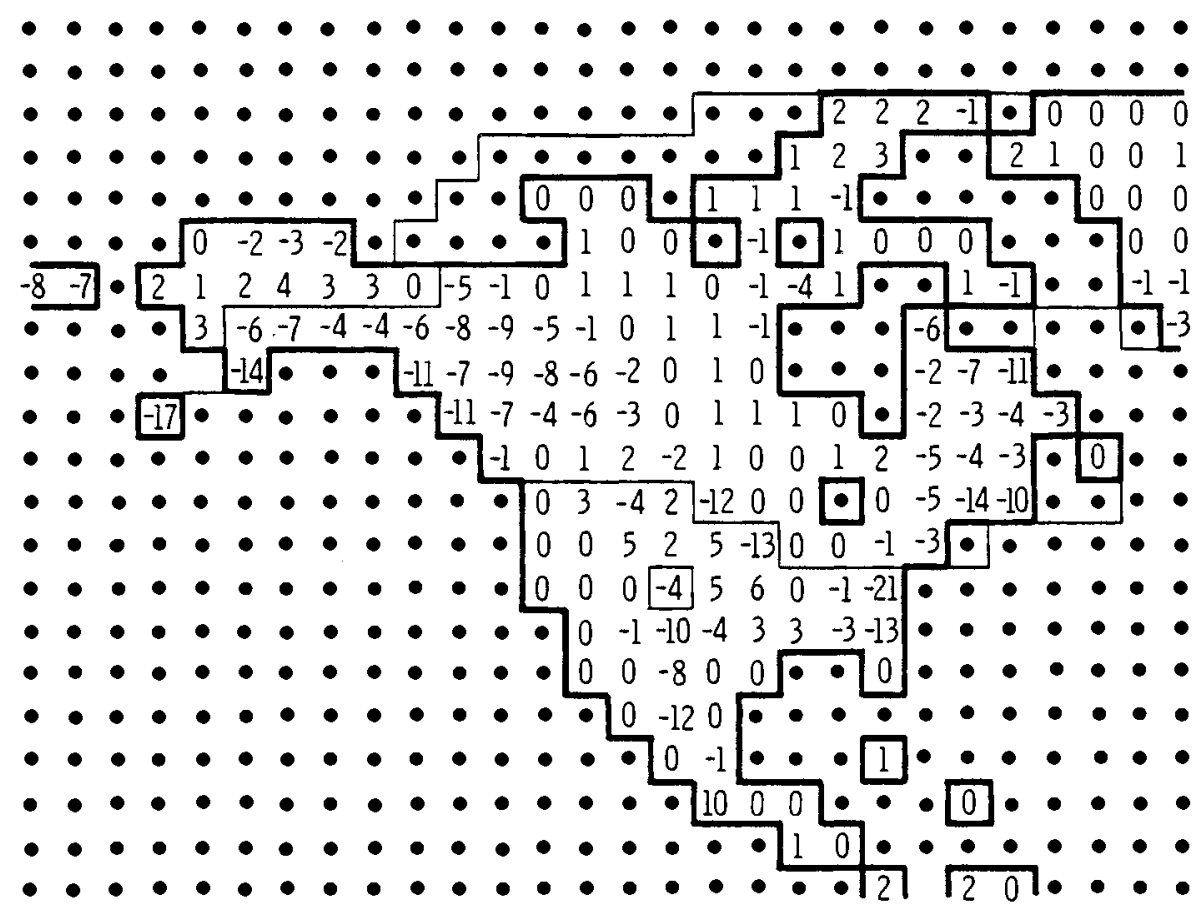

FIGURE 1. Calculation of Difference of Summer Precipitation in $\mathrm{mm}$. Day-1 Between 18,000 Years B.P. and Present Day, by Members of CLIMAP Group (Map supplied by T. Hughes.) 


\section{ISOSTATIC REBOUND RATES: POTENTIAL FOR AND MAGNITUDE OF FRACTURING}

A thorough study of the deformation of the earth's crust under superimposed loads has been made by Brotchie and Silvester (1969). Their earth model is a uniform, elastic, spherical shell enclosing a viscous liquid. With a crust $37 \mathrm{~km}$ thick and reasonable elastic constants, Brotchie and Silvester calculate stresses and deflections due to an ice sheet of central thickness 3000 meters and radius 1450 kilometers, approximating a thin Laurentide ice sheet. Their values are as follows:

\begin{tabular}{|c|c|c|c|c|c|c|c|c|c|c|}
\hline $\begin{array}{l}\text { Distance from } \\
\text { center, } \mathrm{km}\end{array}$ & 0 & 290 & 580 & 870 & 1160 & 1450 & 1500 & 2600 & 1700 & 2800 \\
\hline $\begin{array}{l}\text { Deflection, } \\
\text { meters }\end{array}$ & 301.93 & 769.12 & 673.00 & 512.75 & 238.06 & 22.60 & 3.74 & -3.86 & -1.07 & 0.11 \\
\hline $\begin{array}{l}\text { Flexural stres } \\
\text { radial, } \\
\mathrm{N}^{-2} \times 10^{-3}\end{array}$ & -1627 & -1479 & -1503 & -1483 & -1988 & 10,300 & 7383 & 1231 & -402 & -180 \\
\hline $\begin{array}{l}\text { Flexural stres } \\
\text { tangential, } \\
N \mathrm{~m}^{-2} \times 10^{-3}\end{array}$ & -1627 & -1495 & -1500 & -1495 & -1520 & {$[486$} & 1225 & 253 & -59 & -33 \\
\hline $\begin{array}{l}\text { Shear stress, } \\
\text { if } m^{-2} \times 10^{-3}\end{array}$ & 3 & 15 & 9 & 9 & -31 & 104 & -584 & -356 & -14 & 26 \\
\hline
\end{tabular}

Brotchie and Silvester (1969) state that "the corresponding stresses appear to be sufficient to cause surface cracking." Peltier and Andrews (1976) calculate the world-wide response to a distribution of ice sheets and obtain results in agreement with observed sea-level changes. Weertman (1978) analyses the stresses that would be obtained for a "creep law" mantle. Although his approach differs from Brotchie and Silvester's "power law" approach, Weertman sti11 obtains stresses of 30-300 bars.

Stresses are greatest at the edge of the ice sheet. Both the radial and tangential stresses appear sufficient to give fracturing. Fracturing, thus caused, may be responsible for the initiation of the Great Lakes and other lakes marginal to the Laurentide ice sheet. Some of these lakes are radial to the ice sheet, and others are tangential. Faults along the coast of Maine, probably initiated by ice-sheet margin stresses, are still active due to isostatic rebound (Rand and Gerber 1978). 
Fracturing is most likely to occur in zones previously weakened, so that new ice sheets may not cause new fracturing patterns. Nevertheless, it seems wise to avoid siting waste repositories in areas likely to be covered by ice sheets. Changes in load due to sea-level variations in the Gulf of Mexico seem unlikely to produce stresses sufficient to cause fracturing in the northern Gulf Coast region. 
STRESSES AND REBOUND RATES ASSOCIATED WITH ICE-SHEET LOADING AND UNLOADING

Brotchie and Silvester's (1969) calculations of stresses beneath an ice sheet are for an earth model with a crust, which is a uniform, elastic, thin, spherical shell, enclosing a viscous liquid. The flexural stresses generated at the edge of a model parabolic ice sheet, radius $1450 \mathrm{~km}$, central thickness $3 \mathrm{~km}$, are of the order of 10 bars, which "appears to be sufficient to cause surface cracking." Even with a creep-law mantle (Weertman 1978), the stresses are still of the same order of magnitude: "Stresses are some fraction of 30-300 bars. It seems not unreasonabie to expect that the stresses that produce flow in the mantle are of the order of magnitude of 50 bars plus or minus half an order of magnitude."

As the ice sheet expands and contracts, zones where the maximum flexural stress is of the order of 10 bars will cover most of the glaciated area. Surface cracking will be more likely in those areas where the rock is already weakened by faulting and fissures. The vertical movement associated with the isostatic processes in a given zone will be most pronounced at the times of maximum change of ice thickness, but because of the finite "relaxation time" for those isostatic processes, the movements will continue for several thousand years after the load change. Walcott (1972), summarizing much data, reports that, near the centers of the former ice sheets, uplift velocities of about $2 \mathrm{~cm} \mathrm{yr}^{-1}$ have continued for the last 6000 years.

Rand and Gerber (1978) report that still-active faults on the Maine coast can be attributed to continuing isostatic uplift following deglaciation. The author has not been able to find any other account of faulting or surface fracturing in deglaciated areas that has been attributed to stresses caused by ice-sheet loading (as postulated by Brotchie and Silvester). In general, the areas at the edges of ice sheets were depositional areas; most are covered with glacial debris, so the absence of reports of surface fracturing is not a sure indicator that the fracturing does not exist.

Other factors being equal, one should avoid, as possible disposal sites, the areas covered by past ice sheets or likely to be covered by future ones. 


\section{CONTINENTAL ICE MELTING AND RIVERS OF LIMITED DURATION}

With reasonable assumptions of the ice front in future glaciations and of the crustal tilting due to ice loading, it should be possible to map likely courses of major rivers produced by melting ice. Unless ice extends very much further south than in the Kansan stage, it seems unlikely that any new major valleys will be cut (Clark and Stearn 1968). Specific potential sites in the Gulf coast region need careful attention from this point of view. Sites on plateaus in New Mexico seem immune. 


\section{CORRELATION OF CONTINENTAL GLACIATION EPISODES TO HARMONIC ANALYSIS}

OR "MILANKOVITCH" STUDIES

At the Columbus Glaciology Workshop, T. Hughes reported that none of the CLIMAP studies had shown a significant change in solar radiation in high latitudes, due to the 95,000-year obliquity perturbation. The 100,000-year periodicity in the oxygen-isotope record is the dominant one for the last 300,000 or 600,000 years (Hays et a1. 1976) but perhaps not further into the past. The obliquity perturbations might be the trigger for some other mechanisms affecting earth climate, including periodic world-wide volcanic eruptions.

Weertman (1976) has developed an ice-sheet generation model which responds to Milankovitch variations, but which needs a higher accumulation rate than seems consistent with the current atmospheric circulation models for glacial conditions (Gates 1976; Williams et a1. 1974).

Although the causes of ice ages are not known, it is prudent in the AEGIS stidy to assume that the present interglacial will continue for only a limited period, perhaps 4000 years, and that subsequently an ice sheet, at least equal in size to the Wisconsinan Laurentide ice sheet, will form over North America. 
CONTINENTAL GLACIATIONS AND HARMONIC ANALYSES OF "MILANKOVITCH"

RADIATION VARIATIONS

Although the oxygen-isotope variations in the ocean sediment cores show a 100,000-year period for the last 300,000 years (and perhaps the last 600,000 years), the Milankovitch orbital perturbation with the 95,000-year period, the elliptical orbit change, by itself produces changes in radiation at high lati. tudes that are much smaller than those due to the shorter-period perturbations. The possibility must be allowed that the 95,000-year period forces act as a trigger or catalyst to other dynamic factors on earth. From the relationships between dirt content of ice cores and oxygen-isotope variations, it is possible that these other dynamic factors could include volcanism (Thompson et a 1. 1975).

Alternatively, the periodicities of the Northern Hemisphere glaciations could be completely unrelated to "Milankovitch" perturbations of the geometry of the earth-sun system. Budd (1975), by adjusting the parameters to the dynamics of the Antarctic ice sheet, is able to produce models that show periodic surging, with periods that are close to those observed. The mode 1 may be open to criticism, because the physical justification of Budd's "lubrication theory" does not seem very strong. The relationship between major surges of the Antarctic ice sheet and the initiation of Northern Hemisphere glaciations (Hollin 1977) is not yet firmly established, but it certainly cannot be dismissed.

In addition to the Milankovitch analysis, AEGIS might attempt to assess: 1) the effect of changes in carbon dioxide content of the atmosphere on global temperatures (Broecker 1975; National Academy of Sciences 1977), 2) the possibility of extensive control of climate (perhaps by control of $\mathrm{CO}_{2}$ content of the atmosphere) to offset climatic changes that might have been caused by Milankovitch perturbations or other causes, and 3) the possibility of intro. ducing the parameters of a Budd-type surge mechanism into the pilot program $\operatorname{logic}$. 


\section{POSSIBLE EXTENT OF NORTH AMERICAN ICE SHEETS IN THE NEAR FUTURE}

If the "Milankovitch" perturbations of the earth-sun geometry, leading to changes in insolation of the earth, are the factors primarily responsible for major climatic changes in the past, and if man's influence on the climate, deliberate or accidental, does not become significant, it may soon be possible to project climatic changes for the future by the kind of "Milankovitch" analysis discussed by M. Schwartz at the Battelle Workshop.

So far, however, attempts to show close relationships between ocean-core oxygen isotope ratio profiles and past radiation variations have not been wholly successful. The oxygen isotope profiles can be interpreted in terms of variations of "ice volume on earth," but the "stages" in the oxygen profiles (e.g., Shackleton and Opdyke 1973; Figure 2) cannot be closely related to the named glacial "stages," whose limits have been mapped in the Northern Hemisphere by glacial geologists (e.g., Flint 1971; Figure 3).

Although the causes of major climatic changes are not known, it is prudent to assume that they will continue and that the next glacial stage could be as severe as any in the past (perhaps corresponding to -1.0 on Shack leton and Opdyke's scale). In such a glaciation, the glacial limits in the Midwest U.S.A. could extend south beyond the "Kansan" stage boundary by a few hundred kilometers.

In the past, the Columbia River Plateau, New Mexico, and Gulf Coast sites were not subjected to continental glaciation, but lobes of the Cordilleran ice sheet, 18,000 years B.P., did extend into the northern parts of Washington. In a future ice age that ice sheet could be more extensive, and by coalescing with more extensive mountain glaciations from Mt. Rainier to the west and the Bitter Root Range to the east, could extend to possible repository sites on the Columbia River Plateau. The extent of those mountain glaciations, 18,000 years B.P., has been mapped by John Hollin, as part of the CLIMAP project (Figure 4). As in the Alps, the mountain glaciers in and near Washington state do not seem to have extended for more than about $100 \mathrm{~km}$ beyond the ir 


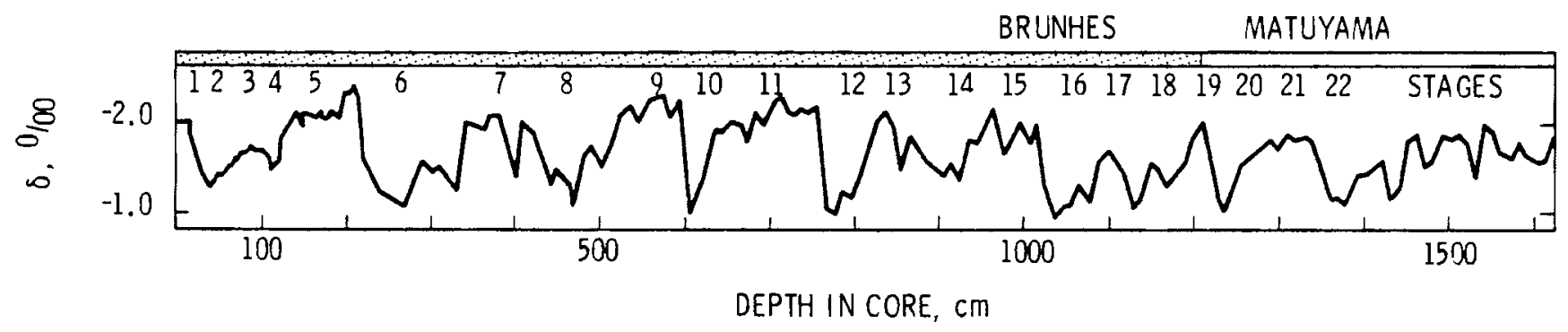

FIGURE 2. Oxygen Isotopic Composition of $G$. Sacculifera in Core V28-238 Complete Record to $1600 \mathrm{~cm}$, Expressed as Deviation o/oo from Emiliani B1 Standard (from Shackleton and Opdyke 1973).

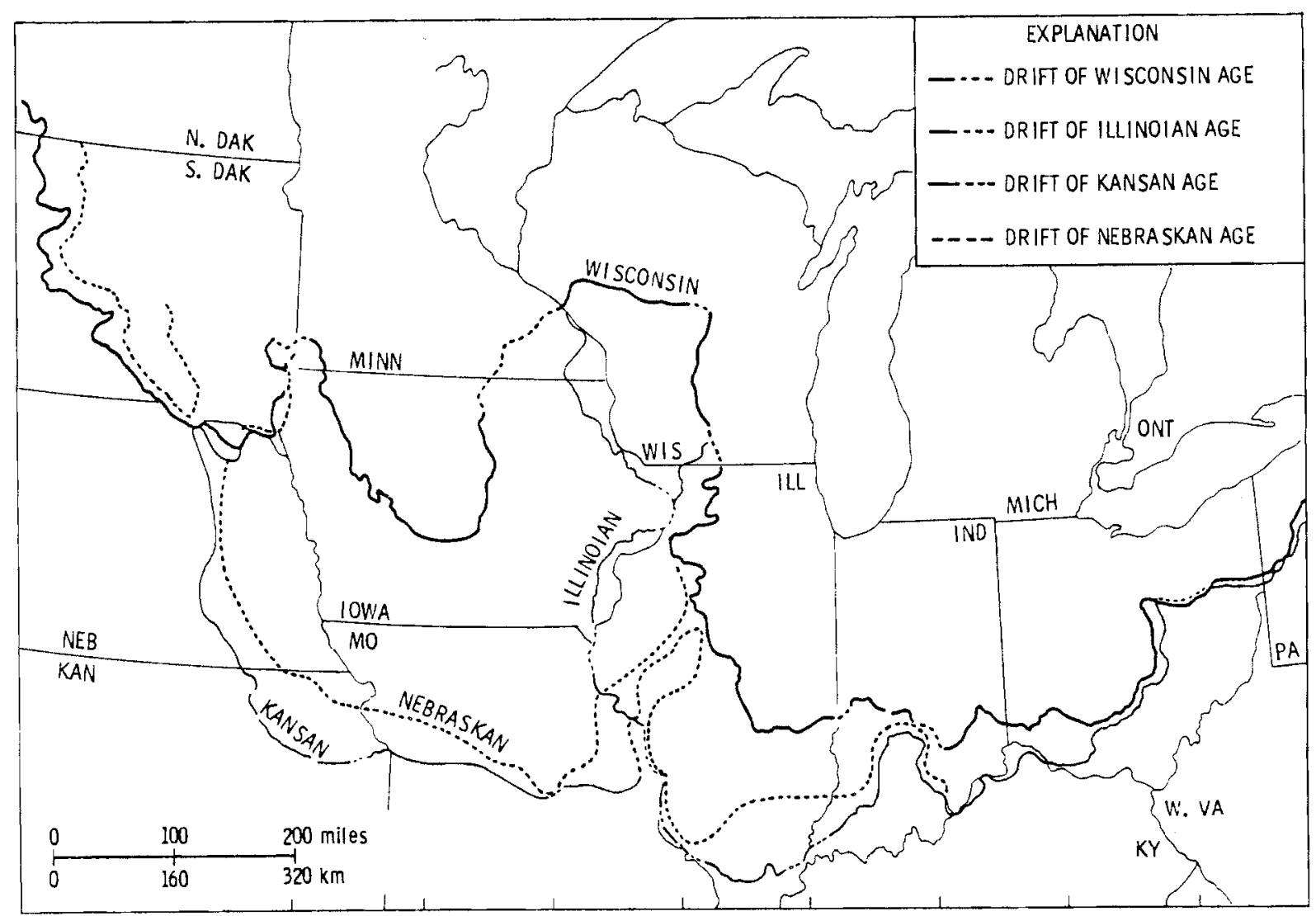

FIGURE 3. Known and Inferred Outer Limits of Four Glacial Stages in Central North America (Modified from Flint et al. 1959) (From Flint 1971) 


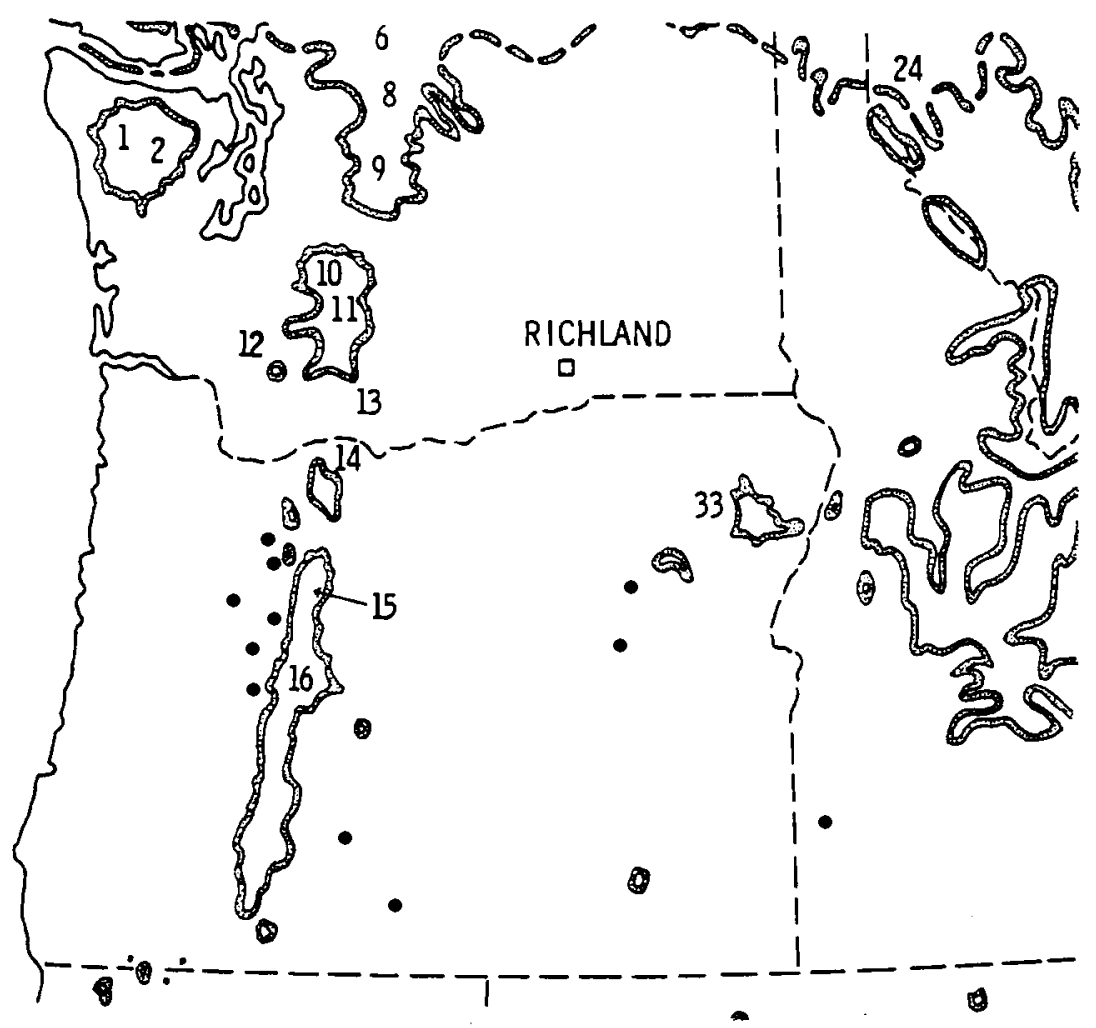

FIGURE 4. Part of John Hollin's Map of Mountain Glaciers in the U.S.A., 18,000 Years Ago, From CLIMAP. (Numbers Identify Sites of Present Glaciers).

present limits. Hence, the probability that a Columbia River Plateau repository site would be covered by ice in the next milition years is seen as finite but sma11. To be conservative, it is suggested as being 0.5 for the AEGIS analysis.

In the event of a glaciation of most of Washington State, a Columbia River Plateau repository site would probably be near the ice edge, where the flexural and shear stresses are largest (Brotchie and Silvester 1969) and where the probability of surface fracturing is greatest. On these grounds, a Columbia River Plateau site appears to be less secure than those more remote from possible continental glaciation. 


\section{OTHER FACTORS CONTROLLING THE SIZE OF ICE SHEETS}

The factors that control the southward extent of North American ice sheets include summer air temperatures, annual snow accumulation, and the degree of coupling between the ice sheet and the underlying material, especially near the periphery of the ice sheet. The coupling is controlled by the quantity of free water at the base of the ice and also by the nature of the regolith. Clays, for example, can support a smaller shear stress than gravels, so that, with all other factors constant, an ice sheet over a clay substratum would be thinner and more extensive than one over gravels.

Before any Pleistocene ice sheet covered the Midwest, the regolith consisted of soils developed on Paleozoic rocks. After the first glacial cycle, the regolith was till, which had a much greater porosity than the pre-existing soil.

The dimensions of an ice sheet are also critically dependent on the availability of free water at the subglacial surface. With basal water, the ice sheet can become uncoupled from the underlying material over large areas. It can then slump forward, perhaps for several hundred kilometers, producing a thin edge to the ice sheet. Sugden (1977) has a "low profile" for part of the Laurentide ice-sheet edge in Montana, to fit the field evidence.

In turn, the nature of the regolith is again important; ti11, being more porous than soil, needs more free water to saturate it and to produce the same degree of uncoupling. 


\section{CONSIDERATION OF A PERMAFROST SITE IN NORTHERN ALASKA}

\section{FOR NUCLEAR WASTE DISPOSAL}

At the ad hoc glaciology workshop of May 1978, T. Hughes suggested that consideration be given to a site in northern Alaska for nuclear waste disposal. This site would need to be located sufficiently far north of the Brooks Range to be outside the range of glacial advances, and far enough from the Arctic Ocean shore for the site to be unaffected by marine transgressions of the kind that have occurred in the last 18,000 years (Hamilton and Porter 1975; Sellman and Brown 1973).

In this North Slope area the permafrost thickness exceeds 300 meters, except locally, and has persisted through the present interglacial period. The permafrost layer offers an excellent additional barrier for the containment of nuclear waste that might be buried in suitable rock units below the permafrost layer. The permafrost has many of the self-sealing properies of salt, and nuclear waste could be distributed with such a density of containers that significant melting of the permafrost did not occur. 


\section{REFERENCES}

Broecker, W. 1975. Climatic change; are we on the brink of a pronounced global warming? Science, 189:460-463.

Brotchie, J. F. and R. Silvester. 1969. On crustal flexure. Journal of Geophysical Research, 74:5240-5252.

Budd, W. F. 1975. A first simple model for periodically self-surging glaciers. Journal of Glaciology, 14:3-21.

Budyko, M. I. 1978. The heat balance of the Earth. In Climatic Change, ed. J. Gribben, C.U.P., pp. 85-113.

Calkin, P. E., R. H. Behling, and C. Bul1. 1970. Glacial history of Wright Valley, Antarctica. Antarctic Journal of the U.S., pp. 22-27.

Clark, T. H. and C. W. Stearn. 1968. Geological Evolution of North America, Rona id, New York.

CLIMAP project members. 1976. The surface of the Ice-age earth. Science, 191:1131-1137.

Curray, J. R. 1965. Late Quaternary history, continental shelves of the United States, in The Quaternary of the United States, ed. H. E. Wright and D. G. Frey, Princton University Press, pp. 723-735.

Drewry, D. J. 1976. Deep-sea drilling from the Glomar Challenger in the Southern Ocean. Polar Record, 18:47-77.

Emiliani, C. and others. 1975. Paleoclimatological analys is of late Quaternary cores from the northeast Gulf of Mexico. Science, 189:1083-1088.

Flint, R. F. 1971. Glacial and Quaternary Geology. John Wiley and Sons.

Gates, L. 1976. Mode11ing the Ice Age climate. Science, 191:1138-1140. See also: Gates, W. L. 1977. The numerical simulation of ice age climates with a global general circulation model, Rand Corporation.

Goldthwait, R. P., A. Dreimanis, J. L. Forsyth, P. F. Karrow, and G. W. White. 1965. Pleistocene deposits of the Erie Lobe, in The Quaternary History of the United States, ed. H. E. Wright and D. G. Frey, Princeton University Press, pp. 63-97.

Gow, A. J. and T. Williamson. 1971. Volcanic ash in the Antarctic ice sheet and its possible climatic implications. Earth and Planetary Science Letters, 13:210-218. 
Hamilton, T. D. and S. C. Porter. 1975. Itkillik Glaciation in the Brooks Range, Northern Alaska. Quaternary Research, 5:471-497.

Hammer, C. U. 1977. Past volcanism revealed by Greenland ice sheet impurities. Nature, 270:482-486.

Hays, J. D., J. Imbrie, and N. J. Shackleton. 1976. Variations in the Earth's orbit: pacemaker of the ice ages. Science, 194:1121-1132.

Hollin, J. T. 1962. On the glacial history of Antarctica. Journal of Glaciology, 4:173-195.

Hollin, J. T. 1977. Thames interglacial sites, Ipswichian sea levels and Antarctic ice surges. Boreas, 6:33-52.

Kellogg, W. W. 1978. Global influences of mankind on climate. In Climatic Change, ed. J. Gribben, C.U.P. pp. 205-227.

Kennett, J. P. and N. J. Shackleton. 1975. Laurentide ice sheet melt water recorded in Gulf of Mexico deep sea cores. Science, 188:147-150.

Mathews, W. H. 1975. Cenozoic erosion and erosion surfaces of eastern North America. American Journal of Science, 275:818-824.

Mayewski, P. 1975. Glacial geology and late Cenozoic history of the Transantarctic Mountains, Antarctica. Ohio State University, Institute of Polar Studies Report 56.

McGinnis, L. D. 1968. Glaciation as a possible cause of mineral deposition. Economic Geology, 63:390-400.

Mercer, J. H. 1978. West Antarctica ice sheet and $\mathrm{CO}_{2}$ greenhouse effect: a threat of disaster. Nature, 271:321-325.

Mueller, E. H. 1965. Quaternary geology of New York, in The Quaternary History of the United States, ed. H. E. Wright and D. G. Frey, Princeton University Press, pp. 99-112.

National Academy of Sciences. 1977. Energy and Climate, report of committee, $158 \mathrm{p}$.

Nye, J. F. 1976. Water flow in glaciers: jokulhlaups, tunnels and veins. Journal of Glaciology, $17: 181-207$.

Peltier, W. R. and J. T. Andrews. 1976. Glacial-isostatic adjustment-I. The forward problem. Geophysical Journal of Royal Astronomical Society, $46: 605-646$. 
Rand, J. R. and R. G. Gerber. 1978. Late Pleistocene Deformation of Bedrock and Ti11, Sears Island, Searsport, Maine. Abstracts With Programs, 13th Annual Meeting of the Northeastern Section, Geological Society of America, March 9-11, 1978, Boston, Massachusetts.

Rudd iman, W. F. 1977. Late Quaternary deposition of ice-rafted sand in the subpolar North Atlantic (lat. 40 to $65 \mathrm{~N}$ ). Bulletin of the Geological Society of America, 88:1813-1827.

Sellman, P. V. and J. Brown. 1973. Stratigraphy and diagenes is of perennially frozen sediments in the Barrow, Alaska, Region. Permafrost, North American Contribution, National Academy of Sciences, pp 171-181.

Shackleton, N. J. and N. D. Opdyke. 1973. Oxygen isotope and paleomagnetic stratigraphy of Equatorial Pac if ic Core $V$ 28-238: oxygen isotope temperatures and ice volumes on a $10^{5}$ and $10^{6}$ year scale. Quaternary Research, 3:39-55.

Shack leton, N. J. and R. K. Matthews. 1977. Oxygen isotope stratigraphy of late Pleistocene coral terraces in Barbados. Nature, 268:618-620.

Stuiver, M., I. C. Yang, and G. H. Denton. 1976. Permafrost oxygen-isotope ratios and chronology of three cores from Antarctica. Nature, $261: 547-550$.

Sugden, D. E. 1976. A case against deep erosion of shields by ice sheets. Geology, 4:580-582.

Sugden, D. E. 1977. Reconstruction of the morphology, dynamics and thermal characteristics of the Laurentide Ice Sheet at its maximum. Arctic and Alpine Research, 9:21-47.

Thompson, L. G., W. L. Hamilton, and C. Bul1. 1975. Climatological implications of microparticle concentrations in the ice core from "Byrd" station, western Antarctica. Journal of Glaciology, 14:433-444.

Walcott, R. I. 1972. Past sea levels, eustacy, and deformation of the earth. Quaternary Research, 2:1-14. See also: Reviews of Geophysics and Space Physics, 10:849-870 (1972).

Wayne, W. J. and J.H. Zumberge. 1965. Pleistocene geology of Indiana and Michigan, in The Quaternary History of the United States, ed. H. E. Wright and D. G. Frey, Princeton University Press, pp. 63-84.

Weertman, J. 1964. Rate of growth or shrinkage of non-equilibrium ice sheets. Journal of Glaciology, 5:145-158.

Weertman, J. H. 1966. Effect of a basal water layer on the dimensions of ice sheets. Journal of Glaciology, 6:191-207. 
Weertman, H. 1976. On Milankovitch solar radiation and variations in ice sheet sizes. Nature, 261:17-20.

Weertman, J. 1978. Creep laws for the mantle of the earth. Philosophical Transactions, Royal Society of London, A 228:9-26.

White, W. A. 1972. Deep erosion by continental ice sheets. Bulletin of the Geological Society of America, 83:1037-1056.

Williams, J., R. G. Barry, and W. M. Washington. 1974. Simulations of the atmospheric circulation, using the NCAR global circulation model, with Ice Age boundary conditions. Journal of Applied Meteorology, 13:305-317.

Wilson, A. T. 1964. Origin of ice ages: an ice shelf theory for Pleistocene glaciation. Nature, 201:147-149.

Wright, H. E. and C. Matsch. 1973. The Superior and Des Moines Lobes. in The Wisconsinan Stage. Geological Society of America, Memoir 136, pp. 153-185. 
APPENDIX

This section consists of responses to questions generated by PNL AEGIS personne 1 .

Probability that the specific site is being glaciated:

For sites within the areas covered by the Kansan, Nebraskan, Illinoian or Wisconsinan ice sheets or the mountain glaciers of 18,000 years B.P., the probability of being recovered by ice in the next 4000 to 10,000 years is somewhere near 0.25 or 0.5 (still assuming that man will not have learned to control climate). The probability of these areas being recovered by ice in the next one million years is close to one.

For sites in the Gulf Coast region and New Mexico the probability of ice covering in 10,000 years is close to zero. For Columbia River Plateau sites, the probability is finite but small. It may possibly be 0.1 but is certainly not more than 0.5 .

Probability that the "trapped lake" phenomenon will occur at the site:

This question is interpreted in terms of the "probability that a wetbased glacier will occur at the site," because the hydrological and recharge effects appear to be identical. At some stage in the glacial cycle a wetbased glacier will cover nearly every place within the glaciation limits. The probabilities from the previous section can be used for this section also. Maximum incremental pore pressure factor associated with a trapped lake:

Sugden's and CLIMAP's reconstructions can be used to determine the range of ice thickness at a specific point. With a wet-based glacier at that point the incremental pore pressure is 0.09 bars per meter of ice thickness.

Maximum rate that ice will build up at a site:

The maximum rate for ice build-up at a site will be the annual snow accumulation at that site. Weertman $(1964,1976)$ gives a high accumulation rate: 0.6 meters (of ice) per year. 
Maximum thickness of ice sheet:

The CLIMAP reconstruction gives estimates for the maximum thickness of ice sheets of Laurentide dimensions. A more extensive ice sheet will be thicker, but a change of $300 \mathrm{~km}$ in the radius of a $1500 \mathrm{~km}$ ice sheet increases the central thickness by only 10 percent at most.

Relationship between ice loading and land subsidence:

The Brotchie and Silvester (1969) curves can be used to answer this question.

Probability of a Missoula-type flood:

This probability is site-specific. For New Mexico the probability is very close to zero; for the Columbia River Plateau, it is near one. For the Gulf Coast region, with careful selection of the site, it could be close to zero.

Maximum magnitude of Missoula-type erosion:

Our information is not as good as D. Tubbs'.

Probability that the media will fracture during isostatic rebound:

The author assumes that the question refers to fracturing that could occur during loading or unloading or immediately following. According to Brotchie and Silvester (1969), Peltier and Andrews (1976), and Weertman (1978), for sites within $200 \mathrm{~km}$ of the ice edge, the probability exists that fracturing will occur. The present author cannot be more specific.

The spacing of fractures due to loading and unloading stresses depends on the previous history of the rock as well as its mechanical properties. Probability of a lake forming over the repository subsequent to end of glaciation:

The probability is site-specific. The Great Lakes are sure to be filled after the next glacial cycle. The next ice sheet will also scour out again most of the other lakes produced or enlarged earlier by glacial erosion. 
Also, moraine-dammed lakes will be formed, but the ir positions cannot be predicted. At the end of the last ice sheet, Ohio had perhaps 5 percent of its glaciated area covered by lakes, of average depth 5 meters and nearly all less than 30 meters.

For the Gulf Coast and New Mexico sites, this probability is near zero. Lakes have formed previously on the Columbia River Plateau. The probability of re-flooding is high, almost one.

Maximum sea-level increase:

Maximum sea-level increase from melting of continental ice sheets in Greenland and Antarctica would be about 65 meters.

Maximum sea-level decrease:

CLIMAP maximum ice thicknesses give a 165-meter decrease in sea level. A series of Northern Hemisphere ice sheets that were 300-600 km more extensive could give a 200-meter decrease.

Maximum sea-level change rate:

The steepest slopes on Shackleton and Opdyke's (1973) curve give 50 meters change in 3000 years. Other estimates could be obtained from Weertman (1964). 


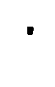




\section{APPENDIX REFERENCES}

Brotchie, J.F. and R. Silvester. 1969. On crustal flexure. Journal of Geophysical Research, 74:5240-5252.

Peltier, W. R. and J. T. Andrews. 1976. Glacial-isostatic adjustment-I. The forward problem. Geophysical Journal of Royal Astronomical Society, $46: 605-646$.

Shackleton, N. J. and N. D. Opdyke. 1973. Oxygen isotope stratigraphy of late Pleistocene coral terraces in Barbados. Nature, 268:618-620.

Weertman, J. 1964. Rate of growth or shrinkage of non-equilibrium ice sheets. Journal of Glaciology, 5:145-158.

Weertman, J. 1976. On Milankovitch solar radiation and variations in ice sheet sizes. Nature, 261:17-20.

Weertman, J. 1978. Creep laws for the mantle of the earth. Philosophical Transactions, Royal Society of London, A 288:9-26. 


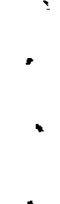




\section{DISTRIBUTION LIST}

No. of

Copies

OFFSITE

2 Argonne National Laboratory

Reference Library

9800 S. Cass Ave.

Argonne, IL 60439

Batte 1le Memorial Institute

Office of Nuclear Waste

Isolation

505 King Ave.

Columbus, $\mathrm{OH} 43201$

Attn: Bever ly Rawles

2 Brookhaven National Laboratory

Reference Section

Information Division

Upton, Long Is land, NY 11973

27 DOE Technical Information Center

John Bird

Geo logy Department

Cornel1 University

Ithaca, NY 14853

Pat Brannen

Sand ia Laboratory

P.0. Box 5800

Albuquerque, NM 87115

John Bredehoeft

U.S. Geological Survey

Reston, VA 22092

Robert Budnitz

U.S. Nuclear Regulatory Commission

Washington DC 29545
No. of

Copies

10 Colin Bull

Office of the Dean

College of Math and Physical

Sciences

Ohio State University

164 W. 17th Ave.

Columbus, $\mathrm{OH} 43201$

Harry C. Burkholder

Office of Nuclear Waste Isolation

Battelle Memorial Institute

505 King Ave.

Columbus, $\mathrm{OH} 43201$

Jim Campbe 11

T39

Division 5413

Sandia Labs

Albuquerque, NM 87185

20 Wayne A. Carbiener

Office of Nuclear Waste

Isolation

Battelle Memorial Institute

505 King Ave.

Columbus, $\mathrm{OH} 43201$

A. A. Churm

DOE Patent Division

9800 So. Cass Ave.

Argonne, IL 60439

H. Clyde Claiborne

Oak Ridge National Laboratory

P.0. Box X, Building 3017

Oak Ridge, TN 37830 
No. of

Copies

James Clark

c/o Eugene Vetter

Route 2, Box 70

Shawano, WI 54166

Neville G. W. Cook

Dept. of Materials Science and

Mineral Engineering

Hearst Mining Building

University of California

Berkeley

Berkeley, CA 94720

Carl R. Cooley

DOE Office of Waste Management

Washington DC 20545

Howard A. Coombs

Department of Geological

Sciences

University of Washington

Seattle, WA 98194

James W. Crosby III

1467 Alpowa

Moscow, ID 83843

Bruce Crowe

Geological Research Group, G-6

Los Alamos Scientific Laboratory

P.0. Box 1663

Los Alamos, NM 87545

Jared Davis

27 Nuclear Regulatory Commission

Washington DC 20555

Stanley M. Davis

810 N. Camino Santiago, \#20

Tuc son, AZ 85705

G. L. DeBuchananne

U.S. Geological Survey

Reston, VA 22092
No. of

Copies

Terry Donich

Lawrence Livermore Laboratory

P.0. Box 808

Livermore, CA 94550

James Duguid

Office of Nuclear Waste

Isolation

Battelle Memorial Institute

Columbus, $\mathrm{OH} 43201$

Don Easterbrook

Western Washington University

Bellingham, WA 98225

Dan Egan

U.S. Environmental Protection Agency

Washington DC 20545

Environmental Protection Agency

Office of Radiation Programs

Technical Assessment Division AW559

Washington DC 20460

J. G. Feinstein

NUS Corporation

4 Research Place

Rockville, MD 20850

Graham E. Fogg

Bureau of Economic Geology

The University of Texas at Aust in

University Station, Box $X$

Austin, TX 78712

Robert M. Garre11s

Dept. of Geologic Sciences

Northwestern University

Evanston, IL 60201 
No. of

Copies

Raymond D. Gastil

Freedom House

20 W. 40 th St.

New York, NY 10018

Earnest Gloyna

National Academy of Sciences

University of Texas

Aust in, TX 78712

George Griswold

Tecolote Corporation

531 Wagon Train Drive SE

Albuquerque, NM 87123

Char les R. Had lock

Arthur D. Little, Inc.

Acorn Park

Cambridge, MA 02140

Colin A. Heath

DOE Division of Waste

Management

Washington DC 20545

William M. Hewitt

Office of Nuclear Waste

Isolation

Battelle Memorial Institute

505 King Ave.

Columbus, $\mathrm{OH} 43201$

John M. Hills

818 Kerbey Ave.

El Paso, TX 79902

Peter L. Hofmann

Office of Nuclear Waste

Isolation

Battelle Memorial Institute

505 King Avenue

Columbus, $\mathrm{OH} 43201$
No. of

Copies

\author{
John T. Holloway \\ Committee on Radioactive Waste \\ Management $\mathrm{JH}-826$ \\ National Academy of Sciences \\ 2101 Constitution Ave. NW \\ Washington DC 20418 \\ Vojin Joksimovic \\ General Atomic Company \\ P.0. Box 81608 \\ San Diego, CA 92138 \\ Lou is S. Karably \\ Law Engineering \\ 2749 Delk Road SE \\ Marietta, GA 30067 \\ R. F. Kaufman \\ Evaluation Branch \\ Office of Radiation Programs \\ U.S. Environmental Protection \\ Agency \\ P.0. Box 18416 \\ Las Vegas, NV 89114 \\ Ralph Kehle \\ 7800 Shoul Creek Blvd. \\ Suite 270 S \\ Aust in, TX 78757 \\ Muzaffer Kehnemuyi \\ Office of Nuclear Waste \\ Isolation \\ Battelle Memorial Institute \\ 505 King Ave. \\ Columbus, $\mathrm{OH} 43201$ \\ John F. Kircher \\ Office of Nuclear Waste \\ Isolation \\ Battelle Memorial Institute \\ 505 King Ave. \\ Columbus, $\mathrm{OH} 43201$
}


No. of

Copies

Charles Koplick

The Analytic Sciences Corp.

6 Jacob Way

Reading, MA 01867

Charles W. Kreitler

Texas Bureau of Economic Geo logy

University Station, Box $X$

Austin, TX 78712

George K. Kukla

Lamont-Doherty Geological

Observatory

Palisades, NY 10964

Donald H. Kupfer

Department of Geology

Lou is ianna State University

Baton Rouge, LA 70803

James G. LaBastie

Law Engineering and Testing Co. 2749 De lk Road SE

Marietta, GA 30067

Ronald B. Lantz

INTERA Environmental

Consultants, Inc.

11511 Katy Freeway

Houston, TX 77079

2 Lawrence Berkeley Laboratory

Reference Library

University of California

Berkeley, CA 94720

2 Lawrence Livermore Laboratory

Reference Library

P.0. Box 808

Livermore, CA 94550

Darrelle I. Leap

USGS, WRD, MS416

Box 25046

Denver Federal Center

Denver, CO 80225
No. of

Copies

Richard Lincoln

Sandia Laboratories

N.N.W.S.I.

NTS Technical Overview

Division 4538

Albuquerque, NM 87185

Stanley E. Logan

Nuclear Waste Management

Program

Los Alamos Technical

Associates, Inc.

P.0. Box 410

Los Alamos, NM 87554

Ear 1 M. Lovejoy

4400 Fairview Road

Reno, NV 89511

Susan J. Mara

SRI International

333 Ravenswood Avenue

Men lo Park, CA 94025

J. B. Martin

Asst. Director for Radioactive Waste Management Branch

NRC Division of Materials and

Fuel Cycle Facility Licensing Washington, DC 20555

Peter D. Mattison

Arthur D. Little, Inc.

Acorn Park

Cambridge, MA 02140

W. C. McClain

Oak Ridge National Laboratory

P.0. Box $X$

Oak Ridge, TN 37830

John T. MCGinn is

Office of Nuclear Waste

Isolation

Battelle Memorial Institute

505 King Ave.

Columbus, $\mathrm{OH} 43201$ 
No. of

Copies

She 1don Meyers

DOE Office of Nuclear Waste Management

Washington DC 20545

Peter A. Mote

Bechte 1, Inc.

P.0. Box 3965

San Francisco, CA 94105

2 Barry Naft

NUS Corporation

4 Research Place

Rockville, MD 20805

2 J. 0. Neff

Department of Energy

Columbus Program Office

505 King Ave.

Columbus, $\mathrm{OH} 43201$

Robert H. Neil

State of New Mexico

Environmental Evaluation Group

P.0. Box 968

Santa Fe, NN 87503

Ivars Neretnieks

Earth Science Division

Lawrence Berkeley Laboratory

University of California

Berkeley, CA 94720

2 Neil Norman

Environmenta 1 Sciences Dept.

Bechtel National, Inc.

P.0. Box 3965

San Francisco, CA 94105

2 Los Alamos Scientific Laboratory

Reference Library

P.0. Box 1663

Los Alamos, NM 87544

2 Oak Ridge National Laboratory

Central Research Library

Document Reference Section

Oak Ridge, TN 37830
No. of

Copies

Suresh B. Pahwar

INTERA Environmental

Consultants, Inc.

11511 Katy Freeway, Suite 630

Houston, TX 77079

Frank L. Parker

Dept. of Environmental

Engineering

Vanderbilt University

Nashville, TN 37235

James Pearson

INTERA Environmental

Consultants, Inc.

11511 Katy Freeway, Suite 630

Houston, TX 77079

George F. Pinder

Dept. of Civil Engineering

Stanford University

Stanford, CA 94305

Larry Ramspott

Technical Program Officer

Lawrence Livermore Laboratory

P.0. Box 808

Livermore, CA 94550

Linda Robinson

NUS Corporation

4 Research Place

Rockville, MD 20850

2 Savannah River Laboratory

Reference Library

Aiken, SC 29801

Maurice L. Schwartz

Department of Geology

Western Washington University

Bellingham, WA 98225

Genevieve Segol

Bechte 1, Inc.

P.O. Box 3965

San Francisco, CA 94105 
No. of

Copies

Herb Shaw

U.S. Geological Survey

Mail Stop 18

345 Midd lefield Road

Men 1o Park, CA 94025

Dillard B. Shipler

Office of Nuclear Waste

Isolation

Battelle Memorial Institute

505 King Ave.

Columbus, $\mathrm{OH} 43201$

James N. Siltanen

General Atomic Company

P.0. Box 81608

San Diego, CA 92138

George M. Slaughter

Law Engineering and Testing Co.

2749 Delk Road SE

Marietta, GA 30067

Barry J. Smernoff

Hudson Institute

Quaker Ridge Road

Croton-On-Hudson, NY 10520

Terry Ste inborn

Lawrence Livermore Laboratories

P.0. Box 808

Livermore, CA 94550

Howard P. Stephens

Sandia Laboratories

N.N.W.S.I.

Division 4538

Albuquerque, NM 87185

James I. Stevens

Arthur D. Little, Inc.

Acorn Park

Cambridge, MA 02140

David B. Stewart

U.S. Geological Survey National Center 959

Reston, VA 22092
No. of

Copies

Robert L. Thoms

Institute for Environmental

Studies

Louisianna State University

Baton Rouge, LA 70803

Newe 11 Trask

U.S. Department of the Interior Geological Survey

Mail Stop 929

Reston, VA 22092

W. S. Twinhofel

USGS

Mail Stop 954

Denver, CO 80225

Maurice D. Veatch

6834 - 51st Ave. NE

Seattle, WA 98115

W. Weart

Division 1140

Sandia Laboratories

Albuquerque, NM 87115

Lawrence Wight

TERA

2150 Shaltuck Ave.

Berkeley, CA 94704

Robert Williams

Electric Power Research

Institute

$3412 \mathrm{Hillview} \mathrm{Avenue}$

P.0. Box 10412

Palo Alto, CA 94304

Charlie Wilson

Earth Sciences Division

Lawrence Livermore Laboratory

Building 90

Berkeley, CA 94720

Paul Witherspoon

Earth Sciences Division

Lawrence Livermore Laboratory

Building 90

Berkeley, CA 94720 
No. of

Copies

FOREIGN

D'Allessandro Avogadro

Commission of European

Commun ities

Joint Rersearch Centre

I-21020 Ispra (Varese)

ITALY

K. H. Hubenthal

Bundesministerium fur Forschung und Technologie

Stressemannstrasse 2

Postfach 200706

D-5300 Bonn

F.R. of GERMANY

Leif Carlsson

Geological Survey of Sweden

Bredgrand 4

S-753 20 UPPSALA

$018 / 15 \quad 5640$

SWEDEN

Center for Atomic Energy Documentation (ZAED)

ATTN: Dr. Bell

Postfach 3640

D-7500 Kar Isruhe

F.R. of GERMANY

Ken Dornuth

Atomic Energy Canada Ltd. Whiteshe 11 Nuclear Research Establishment

Pinawa, Manitoba ROE ILO CANADA

F. Gera

Nuclear Energy Agency/OECD

38 boulevard Suchet

F-75016 Paris

FRANCE
No. of

Copies

2 INIS Clearinghouse

International Atomic Energy Agency

P.0. Box 590

A-1011, Vienna

AUSTRIA

Klaus Kuhn

Institut fur Tiefagerung

Wissenschaftliche Abteilung

Berliner Strasse 2

D-3392 Clausthal - Zellerfeld

F.R. Of GERMANY

Hans W. Levi

Hahn-Meitner-Institut fur Kernforschung

Glienicker Strasse 100

D-1000 Berlin 39

F.R. of GERMANY

Library

Studsvik Energiteknik $A B$

S-611 01 Nykoping

SWEDEN

Glenn Merrett

Storage and Disposal Branch

Whiteshe 11 Nuclear Research Establishment

Pinawa, Manitoba ROE $1 \mathrm{LO}$

CANADA

Takeh ico Ngamatsu

Geologist

Chief Representative Vancouver Office

Mitsubishi Metal Corporation

78 Granville Square

200 Granville Street

Vancouver, BC V6C 1S4

CANADA 
No. of

Copies

Franz Peter Oesterle

Physikalisch-Chemische Bundesanstalt

Bundesallee 100

D-3300 Braunschweig

F.R. Of GERMANY

F. P. Sargent

Atomic Energy of Canada, Ltd. Whiteshe 11 Nuclear Research

Establishment

Pinawa, Manitoba ROE 1 LO

CANADA

Nor itaka Sato

Chief Geologist, Domestic

Exploration \& Nuclear

Resources

Mitsubishi Metal Corporation

1-5-2 Ohte-Machi

Chiyoda-Ku, tokyo

JAPAN

Egbert Schapermeier

Battelle-Institute e.v.

Am Romerhof 35

D-6000 Frankfurt am Main 90

$F$. R. of GERMANY

Tjalle Vandergraff

Atomic Energy of Canada Limited

Whiteshe 11 Nuclear Research

Establishment

Pinawa, Manitoba ROE 1 LO

CANADA

\section{ONSITE}

5 Department of Energy

0. J. Elgert

H. E. Ransom
No. of

Copies

7 Rockwell Hanford Operations

J. J. Schreiber

D. J. Squires

F. R. Standerfer

R. L. Biggerstaff

D. J. Brown

R. A. Deju

G. S. Hunt

R. E. Isaacson

G. L. Jones

Rockwe 11 Document Control

45 Pacific Northwest Laboratories

E. M. Arnold

G. L. Benson

A. Brandstetter (10)

R. A. Craig

W. J. Deutsch

F. H. Dove

M. A. Harwe 11

M. R. Kreiter

J. W. Lindberg

R. F. McCallum

K. S. Murthy

G. M. Petrie

A. M. Platt

J. F. Relyea

B. L. Scott

J. G. Stephan

J. A. Stottlemyre

R. W. Wallace

J. T. Zellmer

Technical Information Library

(5)

Publishing Coordination $\mathrm{SH}(2)$

Water and Land Resources

Department Library (10) 